\title{
RESEARCH ARTICLE \\ Heat Resistance of Probiotic Candidate Enterococcus faecalis R22B in Different Matrices
}

Shanti Dwita Lestari*, Rinto Rinto, Indah Sri Wahyuni, Sherly Ridhowati, and Wulandari Wulandari

\section{OPEN ACCESS}

Program Studi Teknologi Hasil Perikanan Universitas Sriwijaya, JI. Raya PalembangPrabumulih Km. 32 Indralaya, Ogan I lir 30662, Indonesia

*Corresponding Author:

shantidwita_thi@unsri.ac.id

Received: 22 September 2020

Accepted: 8 March 2021

Published: 24 May 2021

o Squalen Bulletin of Marine and Fisheries Postharvest and Biotechnology, 2021. Accreditation Number: 148/M/KPT/2020. ISSN: 2089-5690, e-ISSN: 2406-9272. doi: $10.15578 /$ squalen. 497

\begin{abstract}
Fermented fish, including rusip and bekasam, contains lactic acid bacteria, some of which have probiotic properties. Considering the beneficial effect, the count of viable cells in probiotic carrier foods must be at least $10^{6} \mathrm{CFU} / \mathrm{g}$ throughout the product shelf-life. The processing and storage condition significantly affect the viability of probiotics in carrier foods. This research was conducted to determine the heat resistance of probiotic candidate Enterococcus faecalis R22B isolated from rusip in three different media: bekasam, rusip, and physiological saline solution $(\mathrm{NaCl} 0.85 \%)$. E. faecalis $\mathrm{R} 22 \mathrm{~B}$ was heated in each medium at a temperature of $70{ }^{\circ} \mathrm{C}$ for $0,2,4,8$, and $12 \mathrm{~min}$. The media characteristics showed differences within the parameters included $\mathrm{pH}$ values of 4.41-6.99; $a_{w}$ 0.67-0.92; moisture content 72.56-98.09\%; ash content 0.69$12.32 \%$; protein content $0-14.7 \%$; fat content $0-0.84 \%$; and carbohydrate content from $0-4.93 \%$. The results showed that the difference in the heating medium had no significant effect $(p>0.05)$ on the heat resistance of the bacteria, as indicated by the $\mathrm{D}_{70}$ value. The required average heating time at $70^{\circ} \mathrm{C}$ to decrease E. faecalis R22B cells by $1 \log _{10}\left(\mathrm{D}_{70}\right.$ value) in bekasam, rusip, and physiological saline media were 3.17, 3.29, and $3.55 \mathrm{~min}$, respectively. Despite having a lower $\mathrm{D}_{\mathrm{T}}$-value, the reduction of bacteria cells in three media heated at $70^{\circ} \mathrm{C}$ showed no difference $(p>0.05)$; therefore, bekasam and rusip are suitable for probiotic carrier food.
\end{abstract}

Keywords: bekasam, D value, heat treatment, pasteurization, rusip

\section{I ntroduction}

Oral probiotics are living microbes that will provide health benefits beyond the basic nutrients they contain (Guarner \& Schaafsma, 1998). Probiotic culture has been widely used in the dairy industry and its derivatives in probiotic carrier foods/beverages. However, people start to reduce their milk-based products due to the high cholesterol content. Moreover, people with lactose intolerance could not consume these products (Sornplang \& Piyadeatsoontorn, 2016). Therefore, it is necessary to develop and study the suitability of probiotic carrier foods/beverages from non-dairy sources.

Fermented fish products such as bekasam and rusip are known as the sources of lactic acid bacteria (LAB) (Desniar, Rusmana, Suwanto, \& Mubarik, 2013; Nurnaafi, Setyaningsih, \& Desniar, 2015; Yuliana, Koesoemawardani, Susilawaty, \& Kurniati, 2018). In addition to their potential health benefit as probiotic sources, bekasam and rusip are also promising functional foods since they contain bioactive peptides with anticholesterol and antioxidant properties (Rinto, Lestari, \& Putri, 2019). In previous studies, we have succeeded in obtaining E. faecalis strain B32B and $\mathrm{R} 22 \mathrm{~B}$; the LAB isolates from bekasam and rusip of silver rasbora fish are potential as probiotics (Lestari, Ridhowati, \& Nopianti, 2017).

The required daily probiotic doses are no less than $10^{6}-10^{7} \mathrm{CFU} / \mathrm{mL}$ (Shah, Ali, \& Ravula, 2000) and $10^{8}$ $10^{10} \mathrm{CFU} / \mathrm{mL}$ (Donnet-Hughes, Rochat, Serrant, Aeschlimann, \& Schiffrin, 1999) to provide physiological and therapeutic effects to the host. To ensure the number of viable counts meets this requirement, the probiotics in the food matrices must survive during processing operations, storage, and gastrointestinal digestion. Bekasam and rusip are fermented products that require a cooking process 
before consumption. This condition will certainly affect the survival of the probiotics in the products. Survival and viability are important parameters considering that viable probiotics are more effective in providing health benefits than non-viable ones. In the development of probiotic carrier foods, it is necessary to conduct an initial study to evaluate the viability of probiotic cells during processing. One of the preservation methods which has been largely used in food processing is heat treatment. Understanding the physiological aspects of microorganisms' survival or inactivation due to heat treatment could help develop more effective processing techniques. Furthermore, consumers will obtain functional and beneficial end products.

Heat resistance studies have been carried out on LAB isolated from cooked sausages (Pérez-Chabela, Totosaus, \& Guerrero, 2008), cheese (Christiansen, Nielsen, Vogensen, Brogren, \& Ardo, 2006; Jordan \& Cogan, 1999), and fermented vegetable (Savedboworn et al., 2014). In addition, studies of LAB stress response to high temperatures have also been carried out on Lactobacillus plantarum (Ferrando, Quiberoni, Reinhemer, \& Suarez, 2015; De Angelis \& Gobbetti, 2004). However, no studies have examined the heat resistance of E. faecalis in different heating media/ food matrices. Heat resistance analysis for LAB is usually carried out using synthetic media, such as Maximum Recovery Diluent (Ahmad, Smith, \& Mahboob, 2002), Brain Heart Infusion (Flahaut, Frere, Boutibonnes, \& Auffray, 1997), and modified de Man, Rogosa, Sharpe broth (Haddaji, Krifi, Lagha, Khouadja \& Bakhrouf, 2015). The use of bekasam and rusip as heating media in this research is the first step to assess the suitability of the two fermented fish products as ready-to-eat probiotic carrier foods. Therefore, this research aimed to determine the chemical characteristics of the medium due to heat intervention on E. faecalis R22B. Also, to suggest a heat treatment condition that encourages its viability.

\section{Material and Methods}

\section{Preparation of Heating Media}

Three types of heating media: bekasam, rusip, and physiological saline solution, were used in this study. The physiological saline was selected as heating menstruum due to its isotonic nature and minimal impact on osmotically driven-cell rupture. Snakeskin gourami bekasam was purchased from the local market in Palembang, while the anchovy rusip was obtained from Bangka Island (Figure 1). A total of $500 \mathrm{~g}$ of each fermented fish were blended using laboratory blender $8010 \mathrm{G}$ (Waring, USA) with the addition of $100 \mathrm{~mL}$ distilled water to facilitate homogenization. Physiological

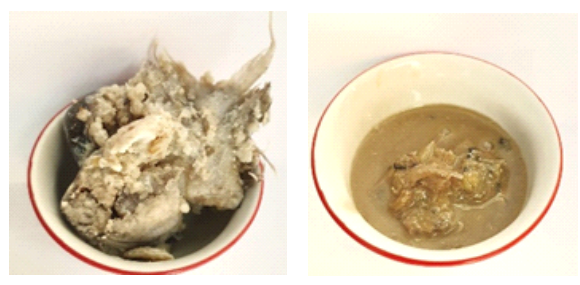

Figure 1. Snakeskin gourami bekasam (left) and anchovy rusip (right).

saline was prepared by dissolving $0.85 \mathrm{~g} \mathrm{NaCl}$ (Merck) in $100 \mathrm{~mL}$ of distilled water (USFDA, 2001). All media were sterilized in an autoclave (Hirayama HL36AE, Japan) at $121{ }^{\circ} \mathrm{C}$ for $15 \mathrm{~min}$ before being chemically characterized and used as heating media.

\section{Characterization of Heating Media}

Chemical profiling included $\mathrm{a}_{\mathrm{w}}, \mathrm{pH}$, moisture content, ash content, carbohydrate content (Luffscrool method), protein content (Kjeldahl method), and fat content (Soxhlet method) were carried out on sterilized media following the procedures adopted from the Association of Official Analytical Chemists (AOAC) as described in Indonesian National Standard SNI 01-2891-1992 (BSN, 1992).

\section{E. faecalis R22B Culture Preparation}

Cultures stock of $E$. faecalis $R 22 B$ were maintained in cryovials (HIMEDIA Viabank 80, India) containing a cryoprotective agent. A total of two glass beads containing a pure strain of E. faecalis R22B culture were removed from cryovials, transferred to a test tube containing $10 \mathrm{~mL}$ of sterile Man Ragosa Sharpe Broth (MRSB) (Merck), and then incubated at $37^{\circ} \mathrm{C}$ for 24 $\mathrm{h}$. Five $\mathrm{mL}$ of the growing culture was subsequently inoculated into $45 \mathrm{~mL}$ of sterile MRSB and incubated for $40 \mathrm{~h}$. Before being added to the heating medium, the number of viable cells present in the culture was enumerated using the total plate count (TPC) method according to SNI 01-2897:2008 (BSN, 2008) and serially diluted with sterile buffered peptone water. A respective volume of $1 \mathrm{~mL}$ aliquots of the diluents were poured with Plate Count Agar (PCA), and the bacterial colonies were counted after $24 \mathrm{~h}$ incubation at $37{ }^{\circ} \mathrm{C}$. The suitable colony counting range was $25-250$ colonies.

\section{Heat Resistance Test}

The assessment of heat resistance was carried out by referring to the method proposed by Jordan \& Coogan (1999) with modifications. A total of $50 \mathrm{~mL}$ culture were homogenized with $450 \mathrm{~mL}$ of bekasam and rusip using a stomacher (Interscience Bag Mixer $400 \mathrm{~W}, \mathrm{USA}$ ) for $30 \mathrm{~s}$. The mixture was then transferred 
into a sterile $10 \mathrm{~mL}$ test tube and closed tightly. Each tube was heated at $70{ }^{\circ} \mathrm{C}$ for $0,2,4,8$, and $12 \mathrm{~min}$ using a closed water bath (Memmert WNB14, Germany). Moreover, the tubes were cooled in ice for $10 \mathrm{~min}$, serially diluted in Maximum Recovery Diluent (MRD), and plated on a sterile petri dish (Sterilin 90, Thermo Scientific) containing MRSA $+\mathrm{CaCO}_{3}$ (Merck) media. After $36 \mathrm{~h}$ incubation at $37^{\circ} \mathrm{C}$, the number of viable cells from each dilution was counted.

\section{Determination of $\mathbf{D}_{\mathbf{7 0}}$ Value}

The data obtained were processed using linear regression (Microsoft $\AA$ Excel 2019). The $D_{70}$ value was determined based on the regression curve slope between heating time $(\mathrm{x})$ as independent variables and the number of living cells (y) as the dependent variable.

\section{Data Analysis}

The data obtained were analyzed for variability (ANOVA) using parametric statistics with a randomized block design (RBD) using a 95\% confidence interval. Statistical differences between treatments were analyzed using Minitab 19 (Minitab LLC, USA).

\section{Results and Discussion}

\section{Heating Medium Characteristics}

The main factors that affect the heat resistance of a microbe are water activity $\left(\mathrm{a}_{\mathrm{w}}\right)$, nutrient content, $\mathrm{pH}$ of the heating menstruum, the microbes growth phase, the growth temperature, variations in genus, species, and even strains within the same species (Huertas et al., 2016). Therefore, media characterization is an integral part of microbial heat resistance study. The chemical characteristics of the three heating media used in this study are presented in Table 1.

Based on the chemical analysis, the highest water content and water activity $\left(\mathrm{a}_{\mathrm{w}}\right)$ value were found in $0.85 \% \mathrm{NaCl}$ media. The low $\mathrm{a}_{\mathrm{w}}$ value in rusip is related to salt and sugar molecules that naturally have a high affinity to water and bind the available free water molecules in the material. The low $\mathrm{a}_{\mathrm{w}}$ value of rusip is in line with Rimadhini, Sumardianto and Romadhon (2020) results. This explains the addition of $10 \%$ liquid palm sugar resulted in $\mathrm{a}_{\mathrm{w}}$ value of 0.77 . In this study, the $a_{w}$ value of the rusip was 0.68 , higher than the commercial rusip that contains more salt and palm sugar. In general, the salt concentration in bekasam is $10-15 \%$, while in rusip, the addition is around $20-30 \%$. The relation between $\mathrm{NaCl}$ concentration and $\mathrm{a}_{\mathrm{w}}$ has been described by Chirife and Resnik (1984).

The concentration of $\mathrm{NaCl}$ can be used to predict the $\mathrm{a}_{\mathrm{w}}$ and vice versa. The authors suggest that variation of predicted value due to temperature changes at 15$50{ }^{\circ} \mathrm{C}$ is very low. The high salt concentration will also affect the protein content of the ingredients. Bekasam contains higher dissolved and total carbohydrates measured by the Luffscrool than those of rusip. This is related to the difference in the proportion of carbohydrates used. The source of carbohydrate in the fermentation of bekasam is $15 \%(\mathrm{w} / \mathrm{w})$ rice; while in rusip, the carbohydrate is $10 \%$ (v/w) liquid brown sugar. The presence of rice and brown sugar as carbohydrates promotes the production of organic acids during the carbon metabolism in bacterial cells. The accumulation of acids leads to increased acidity and lower $\mathrm{pH}$ in the final products. Among the three media, bekasam had the lowest $\mathrm{pH}$, with a value of 4.41, while physiological saline had a nearly neutral $\mathrm{pH}$ of 6.99 .

Bekasam is a fermented fish product made by mixing fish, salt, and cooked rice. Although the fish to rice ratio may vary, the salt concentration of $10 \%$ is generally used during bekasam preparation (Nuraini, Ibrahim, \& Rianingsih, 2014; Wikandari, Suparmo, Marsono, \& Rahayu, 2012). On the other hand, higher salt concentration (20-30\%) is used in rusip products combined with $10 \%$ of palm sugar (Huda, 2012; Putri, Budiharjo, \& Kusdiyantini, 2014). This high salt concentration corresponds to the lowest $\mathrm{a}_{\mathrm{w}}$ of the rusip

Table 1. Chemical characterization of heating media

\begin{tabular}{lccl}
\hline Parameters & Bekasam & Rusip & NaCl 0.85\% \\
\hline Moisture (\%) & $72.56 \pm 0.48^{\mathrm{a}}$ & $72.57 \pm 1.09^{\mathrm{ab}}$ & $98.93 \pm 0.15^{\mathrm{c}}$ \\
Ash (\%) & $12.32 \pm 0.37^{\mathrm{c}}$ & $9.26 \pm 0.07^{\mathrm{b}}$ & $0.69 \pm 0.03^{\mathrm{a}}$ \\
Fat (\%) & $0.85 \pm 0.04^{\mathrm{c}}$ & $0.73 \pm 0.04^{\mathrm{b}}$ & $0 *^{\mathrm{a}}$ \\
Dissolved carbohydrate (\%) & $4.93 \pm 0.45^{\mathrm{c}}$ & $1.66 \pm 0.37^{\mathrm{b}}$ & $0^{*^{\mathrm{a}}}$ \\
Total carbohydrate (\%) & $13.82 \pm 0.19^{\mathrm{c}}$ & $11.16 \pm 0.26^{\mathrm{b}}$ & $0 *^{\mathrm{a}}$ \\
Protein (\%) & $14.70 \pm 0.46^{\mathrm{c}}$ & $10.90 \pm 0.59^{\mathrm{b}}$ & $0 *^{\mathrm{a}}$ \\
$\mathrm{pH}$ & $4.41 \pm 0.23^{\mathrm{a}}$ & $4.86 \pm 0.30^{\mathrm{ab}}$ & $6.99 \pm 0.19^{\mathrm{b}}$ \\
$\mathrm{a}$ & $0.87 \pm 0.03^{\mathrm{b}}$ & $0.68 \pm 0.01^{\mathrm{a}}$ & $0.93 \pm 0.01^{\mathrm{c}}$ \\
\hline
\end{tabular}

Note:

Data represent the mean value of three replicates \pm SD. Means within each row with different lowercase letters are significantly different $(p<0.05) . *$ fat, carbohydrate, and protein were not detected in the medium. 


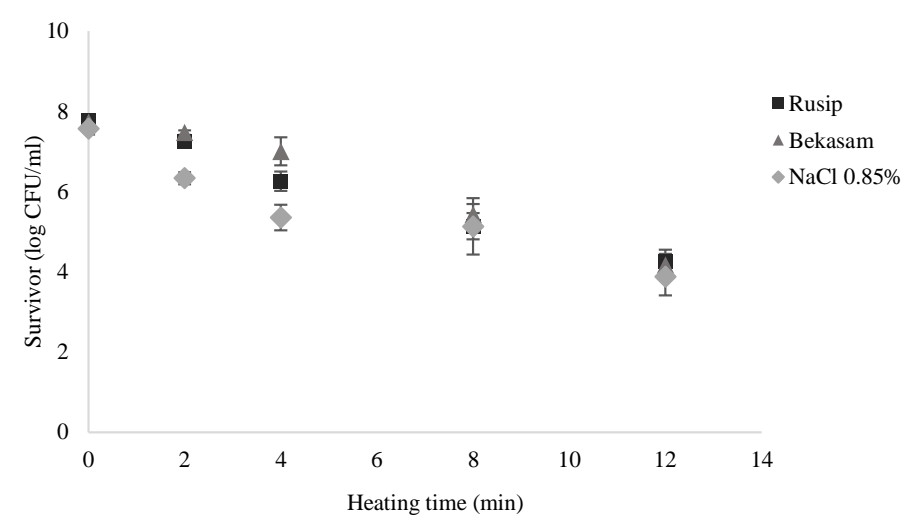

Figure 2. Effects of heating time (min) on the number of survivor cells $\left(\log _{10} \mathrm{CFU} / \mathrm{mL}\right)$ in three different matrices $\rightarrow[($ bekasam $) ;-($ rusip $) ; \multimap(\mathrm{NaCl}$ $0.85 \%)$, all values are of triplicates.

medium. The time required for autochthonous microbes to ferment the fish is generally shorter, approximately 4-14 days. Various bekasam fermentation time has been reported, ranging from 5-7 days (Wikandari et al., 2012) to 14 days (Desniar et al., 2013). As for rusip, a two-week fermentation is commonly practiced (Huda, 2012), even though the product can also be consumed after seven days of fermentation (Putri et al., 2014).

\section{E. faecalis R22B Viability Due to Thermal Treatment in Different Media}

Figure 2 depicts the number of surviving E. faecalis $\mathrm{R} 22 \mathrm{~B}$ cells in various matrices heated at $70{ }^{\circ} \mathrm{C}$. Each point represents the average number of survivors of three replicates. Based on the results, it can be interpreted that in all media, the number of viable cells of E. faecalis R22B decreased along with the longer heating time at $70{ }^{\circ} \mathrm{C}$. The isothermal microbial survival curves are not always linear (Allwood \& Russell, 1970; Corradini, Normand \& Peleg, 2007). In this study, each different heating medium provides specific survival patterns at the same temperature. When the physiological saline medium was heated, the mortality rate of cells was relatively high. This suggests that high $a_{w}$ value has a high proportion of free water molecules. Furthermore, it will promote the convectional heat transfer from medium to bacterial cells. After few minutes, the lower rate of cell death was observed, which was presumably due to the de novo synthesis of heat shock proteins and a loss of cytoplasmatic water during heating, reducing heat convection (de Jonge, 2019). The slightly skewed survivor cell's pattern of $E$. faecalis heated in bekasam medium indicates the presence of cell clumping or the necessity for a certain amount of heat damage to occur before the cells lose their ability to recover (Allwood \& Russell, 1970). In this study, fat and protein molecules of bekasam and rusip were assumed to provide the heat transfer barrier, which delayed the cell's damage, reflecting in the high number of viable cells up to four min of heat treatment.
The $\mathrm{D}_{\mathrm{T}}$ value represents the time required to reduce the number of microbial cells at a certain temperature and substrate type by $90 \%$ and decrease the population by $1 \log _{10}$. The $\mathrm{D}_{\mathrm{T}}$ value of E. faecalis is derived from linear regression equations using the formula $\mathrm{D}_{\mathrm{T}}=1 /$ (- slope). Based on the average number of survival cells from three experiments as indicated in Figure 2 and the respective linear regression curve (Figure 3), the $\mathrm{D}_{70}$ values of E. faecalis on bekasam, rusip, and physiological saline were $3.17,3.29$, and $3.55 \mathrm{~min}$, respectively. The coefficient of determination $\left(\mathrm{R}^{2}\right)$ shows $98 \%$ variability in the number of survivors on bekasam and rusip was due to heating. On the other hand, the $R^{2}$ value of the $\mathrm{NaCl}$ medium was only $91.82 \%$. This indicates that only $91.82 \%$ variability of surviving cell numbers is determined by heating time, while the rest is due to other factors.

Domestically in household kitchens, bekasam and rusip undergo heat treatment prior to serving. Both products are usually sauteed with chilies and onions in a short time between 1-2 min. Sauteing is defined as cooking foods in a thin film of hot oil in a skillet set on a hot burner (Fabbri \& Crosby, 2016). The sauteing temperature in-home preparation can be as low as 93 ${ }^{\circ} \mathrm{C}$ (Lombard, Peffley, Geoffriau, Thompson, \& Herring, 2005) to $120{ }^{\circ} \mathrm{C}$ (Lozano-Castellón et al., 2020). The heat transferred to food products through thermal processing is influenced by heating techniques, the type of heating medium, the physical properties of food such as shape, size, and viscosity, and chemical properties related to the composition of the foodstuff (den Besten, Wells-Bennik \& Zwietering, 2018). Analyzing the heat resistance of a certain bacteria using sauteing process as a model is considered less reliable due to a higher chance of temperature variation. Therefore, in this study, the pasteurization approach was used to assess the heat effect on the survival of E. faecalis R22B. Moreover, this approach may serve as a basis for the development of pouched or canned pasteurized fermented fish as probiotic carrier foods.

Pasteurization is categorized as the mild/moderate heat treatment with a temperature of $<100{ }^{\circ} \mathrm{C}$. 

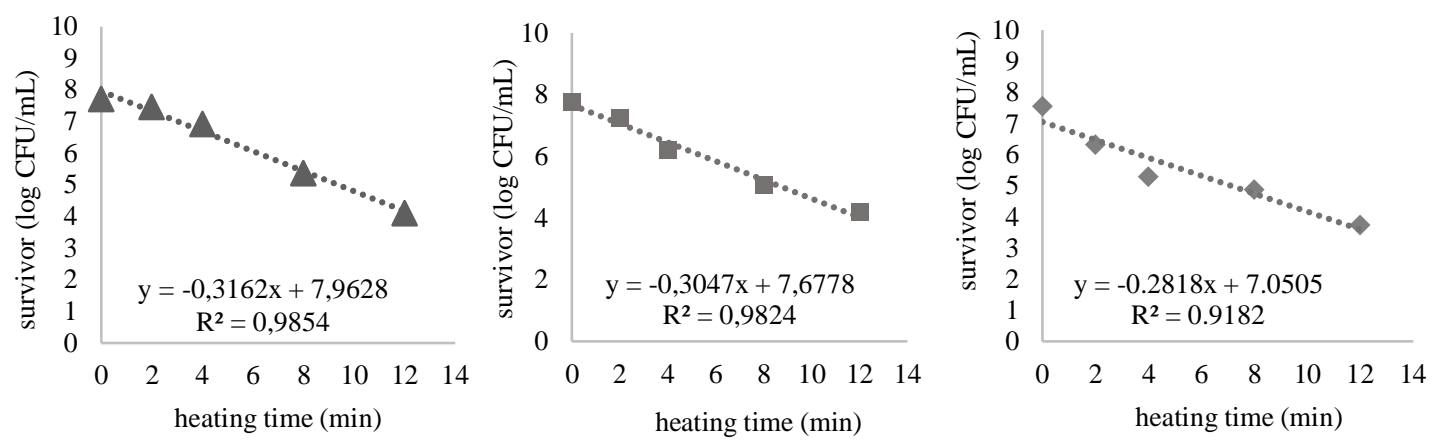

Figure 3. Linear regression of survivor cells $\left(\log _{10} \mathrm{CFU} / \mathrm{mL}\right)$ versus heating time $(\mathrm{min})$ in three different media $-[($ bekasam); $\rightarrow$ (rusip); $\leadsto(\mathrm{NaCl} 0.85 \%)]$, all values are of triplicates.

Pasteurization in fishery products is commonly carried out on hermetically packed crab meat products to eliminate $C$. botulinum spores type E, also nonproteolytic B and F (USFDA, 2020). The process is also carried out to reduce the number of pathogens such as L. monocytogenes and V. vulnificus, also putrefactive bacteria through the inactivation of vegetative cells (Horn, Olsen, Hasell \& Cook, 2015). It is suggested that fish and fishery products have to be adequately pasteurized up to $10 \mathrm{~min}$ at $90{ }^{\circ} \mathrm{C}$ (USFDA, 2020). However, a lower pasteurization temperature of $50{ }^{\circ} \mathrm{C}$ was found effective in reducing Vibrio sp. pathogens in raw oyster from $>100,000$ to non-detectable levels in less than 10 min equal to 2-3 logs reduction of spoilage bacteria (Andrews, Park, \& Chen, 2000). Heat treatment at $70{ }^{\circ} \mathrm{C}$ to $100{ }^{\circ} \mathrm{C}$ can reduce microbial pathogens and kill the vegetative forms of microorganisms. However, this has little or no effect on the spores of bacteria (USFDA, 2018). The temperature of $70{ }^{\circ} \mathrm{C}$ was used following the method proposed by Martinez, Lopez, and Bernardo (2003), who studied the thermal inactivation of Enterococcus faecium.

The heat resistance of bacteria can be determined by D- and z-values (de Jonge, 2019). The estimation of $D_{T}$ value has been used to determine the heat tolerance of certain bacteria in respective food matrices, such as Salmonella Enteritidis in liquid egg products (Kang et al., 2018) and L. monocytogenes and Salmonella Typhimurium in turkey bologna (McCormick, Han, Acton, Sheldon \& Dawson, 2003).

Table 2. $\mathrm{D}_{70}$ value of E. faecalis $\mathrm{R} 22 \mathrm{~B}$ in different heating matrices

\begin{tabular}{clll}
\hline Experimental no. & Bekasam & Rusip & $\mathrm{NaCl} 0.85 \%$ \\
\hline 1 & 3.27 & 3.52 & 2.86 \\
2 & 2.97 & 3.30 & 3.63 \\
3 & 3.26 & 3.05 & 4.17 \\
Average & $3.17 \pm 0.17^{\mathrm{a}}$ & $3.29 \pm 0.23^{\mathrm{a}}$ & $3.55 \pm 0.66^{\mathrm{a}}$ \\
\hline
\end{tabular}

The low $\mathrm{D}_{\mathrm{T}}$ value reflects the bacterial population that is more vulnerable to heat treatment. The $\mathrm{D}_{T}$ value of non-spore bacteria such as Pseudomonas, Achromobacter, Enterobacter, Micrococcus, Lactobacillus at $85^{\circ} \mathrm{C}$ and $65.5^{\circ} \mathrm{C}$, ranged from 0.008 0.01 seconds and 1-3 min respectively (Hackney, Rippen \& Ward, 1991).

Data on Table 2 was compiled based on the $D_{70}$ mean of each treatment in a respected experiment. The difference in the type of heating medium had no significant effect on the $\mathrm{D}_{70}$ value of $E$. faecalis $\mathrm{R} 22 \mathrm{~B}$ $(p>0.05)$. However, the highest $\mathrm{D}_{70}$ value of $E$. faecalis $\mathrm{R} 22 \mathrm{~B}$ was achieved when the bacterial cells were heated in a $0.85 \% \mathrm{NaCl}$ medium.

The factors that trigger the decline in the value of $\mathrm{D}_{\mathrm{T}}$ include the $\mathrm{pH}$ value (too low or high $\mathrm{pH}$ ) and the presence of additive compounds (Horn et al., 2015). The difference in chemical characteristics of the heating medium contributes to a different rate of microbial inactivation at the same temperature (McAuley, Gobius, Britz, \& Craven, 2012). In the current study, physiological salts with a neutral $\mathrm{pH}$ $(6.99 \pm 0.19)$ resulted in a higher $D_{T}$ value than those of other treatments. Despite containing fat and protein that could provide thermal stability and low $a_{w}$ due to the sugar (carbohydrates) and salt content, the low $\mathrm{pH}$ of bekasam and rusip ranges from $4.41 \pm 0.23$ and $4.86 \pm 0.30$, respectively, may trigger microbial sensitivity against heat. The possible mechanism is through the progressive breakdown of cell wall components (Wu, 2008). Heat processes can inactivate vegetative cells due to damage to cell wall components, cytoplasmic membranes, ribosomal RNA, protein denaturation, including ribosomal proteins and enzymes that play an important role in cell metabolism (Wu, 2008). Although the high a tends to decrease microbial resistance to heat, the $\mathrm{D}_{70}$ value of E. faecalis $\mathrm{R} 22 \mathrm{~B}$ in $0.85 \% \mathrm{NaCl}$ medium, which had an $\mathrm{a}_{\mathrm{w}}$ of 0.93 , was insignificantly higher than those in bekasam and rusip media. The neutral $\mathrm{pH}$ value of the corresponding physiological saline solution was predicted to be the 
dominant factor in determining heat resistance. The $\mathrm{pH}$ of heating media is the most critical factor and, at the same time, has a significant influence on the heat resistance of bacteria (Palop \& Martinez, 2012). Microorganisms show maximum heat resistance at neutral $\mathrm{pH}$, and this resistance decreases with increasing acidity of the media (Doyle, Mazzotta, Wang, Wiseman, \& Scott, 2001). Heating bacterial cells at acidic $\mathrm{pH}$ raise their sensitivity due to prompt cytoplasmic acidification and rapid protein denaturation (Cebrián, Condón, \& Mañas, 2017).

The presence of sugar as additives in the heating menstruum would increase the cell's vulnerability to heat (Horn et al., 2015; Bayles, 2004). Both bekasam and rusip contain glucose as they are prepared by adding cooked rice and liquid palm sugar. The combination effects of glucose and low $\mathrm{pH}$ are presumed to impact bacterial cells negatively, contributing to lower $\mathrm{D}_{T}$ values. This result was consistent with that of Bayles (2004). The presence of glucose significantly decreased the heat resistance of L. monocytogenes Scott A challenged at $\mathrm{pH} 4.8$ compared to those treated at $\mathrm{pH}$ 7. The use of sterile TSB as the heating medium led the acid-adapted cells at $\mathrm{pH} 4.8$ more heat-sensitive than those tested at $\mathrm{pH}$ 7. Therefore, the interaction between $\mathrm{pH}$ and the nutrient composition of the heating matrices may determine cross-protection. Ultimately, it generates the heat resistance response. The acid and salt stress combination plays important role in reducing the heat tolerance of bacterial cells, with acid stress being the major determiner of cells' sensitivity to heat (Kang et al., 2018). All previously described mechanisms explain how the D-values were higher in $\mathrm{NaCl} 0.85 \%$ than in bekasam and rusip.

During the interpretation of D-values, a broad spectrum of variables should be addressed. It is due to the D-value is eminently affected by the combination of several factors. In general, the outer and inner membrane, peptidoglycan cell wall, cytoplasmic membrane, nucleoid, RNA, ribosomes, and multiple types of enzymes are among the cellular targets affected by heat. Therefore, they lead to bacterial death or inactivation (Cebrián et al., 2017). E. faecalis and E. faecium are known as heat resistance. This characteristic has been reviewed by Sorqvist (2003) after compiling the results of many heat resistance studies of the respective species. Most of the studies used liquids as a heating medium with $\mathrm{pH}$ values of 68 . The $\mathrm{D}_{60}$ of $E$. faecalis ranged from $66-2,593 \mathrm{~s}$, equal to $1.1-43.2 \mathrm{~min}$. E. faecalis $2350 \mathrm{p} 1$ has been reported to have a $D_{63}$ value of $49 \mathrm{~min}$ and a $\mathrm{D}_{72}$ value of 2.7 min (McAuley.,2012). The range indicates the significant variation in heat resistance exists between strains of this species. However, the test procedures and type of heating medium in each experiment also play an important role. Apart from strain variation, heat resistance is also affected by the age of microorganisms, previous growth and test conditions, exposure to heat shock, acid, and the heating medium composition. Some species are more resistant to heat when tested in foods than in laboratory media (Doyle et al., 2001).

The exposure of bacterial cells to higher temperatures than the optimum growth temperatures could induce the formation of heat-shock proteins that increases their thermal tolerance (McCormick et al., 2003). However, this may occur in the absence of certain limiting factors such as unsuitable pH. It is assumed that during the heating in an acid condition of bekasam and rusip, the formation of the heat-shock proteins was inhibited. This was due to the adaptation of cells to unfavorable acidic conditions. Therefore, the $\mathrm{D}_{\mathrm{T}}$ value of E. faecalis was lower in these media than that in physiological saline solution. Meanwhile, the exposure of heat shock to the cells in physiological saline solution supposedly stimulates the formation of those specific proteins. The unfolding of the proteins resulting from the sudden rise of temperature appears to be the primary signal that initialized the heat shock response (Schumann, 2017). The increase of temperature also promotes physiological changes that extensively enhance the ability of bacterial cells to endure such harmful environmental conditions (Shin, Kang, Kim \& So, 2018), as indicated by high $\mathrm{D}_{\mathrm{T}}$ values.

Horn et al. (2015) formulated the relationship between the chemical characteristics to microbial heat resistance as reflected by the $D_{T}$ value. Some of the factors that increase the $D_{T}$ value include anaerobic conditions during heating, competition with other microbes in the media that trigger changes in the oxidation-reduction potential (Eh) of the material, the fat content, which increases thermal stability, and a decrease in the $a_{w}$ value. A study on Salmonella's resistance to heat using organic wheat flour as food matrices indicates that during the thermal treatment, the $a_{w}$ of food matrices increase simultaneously, resulting in a reduction of thermal resistance of bacterial cells as reflected by low $\mathrm{D}_{\mathrm{T}}$ value (Tadapaneni, Syamaladevi, Villa-Rojas \& Tang, 2017). The extent of such change depends on the composition of foods, including the concentration of salts, lipids, proteins, and other components in the food matrices. The same phenomenon is suggested to take place in bekasam and rusip media. The increase in $\mathrm{a}_{\mathrm{w}}$ as the compensation of increasing temperature made ${ }^{\mathrm{w}}$ E. faecalis cells more susceptible to heat.

In summary, E. faecalis R22B can survive the heat treatment of $70{ }^{\circ} \mathrm{C}$ in bekasam and rusip media, with 
the respective $\mathrm{D}_{70}$ value of 3.17 and $3.29 \mathrm{~min}$. To achieve $>10^{6}$ surviving cells in the pasteurized food matrices and support its function as a probiotic, the number of E. faecalis $\mathrm{R} 22 \mathrm{~B}$ added as adjuncts have to be considered. The addition of $10^{10}-10^{12} \mathrm{CFU} / \mathrm{mL}$ of this strain during bekasam or rusip fermentation is estimated to result in the surviving cell number of $10^{6}$ $-10^{8}$ after heat treatment at $70{ }^{\circ} \mathrm{C}$ for 6.5 and $7 \mathrm{~min}$, respectively. Other cooking methods with higher temperatures lead to further study to observe the heat tolerance improvement of the strain, i.e., stress adaptation and microencapsulation effect. Adapting the cells to high temperature at a slower rate as a pretreatment prior to their application in referred food matrices is known as one factor that improves heat tolerance. It is known that slow heating processes would allow some adjustment by the cells (Shin et al., 2018, Kim et al., 2019). This result is important as primary data to address technological challenges in sustaining the viability of the probiotic culture in the food product during processing and storage.

\section{Conclusion}

This study demonstrated the chemical characteristics of food matrices regarding the heat resistance of E. faecalis $\mathrm{R} 22 \mathrm{~B}$ as indicated by the $\mathrm{D}_{\mathrm{T}}$ value. Heat resistance was insignificantly higher for E. faecalis challenged in physiological saline solution than that in bekasam and rusip media. Among many factors that influence heat resistance, the $\mathrm{pH}$ of the heating medium plays the most important role. The addition of a minimum $10^{10} \mathrm{CFU} / \mathrm{mL}$ of $E$. faecalis $\mathrm{R} 22 \mathrm{~B}$ during fermentation of bekasam and rusip is suggested to acquire the minimum concentration of probiotic bacteria after heat treatment at $70^{\circ} \mathrm{C}$. Further studies are still needed to determine the combination of processing and heating techniques to ensure the loss of pathogenic and putrefying microbes from the material without reducing the viability of the E. faecalis as a probiotic candidate.

\section{Acknowledgments}

The research was funded by DIPA of Public Service Agency of Sriwijaya University 2020, number SP DIPA-023.17.2.677515/2020.

\section{References}

Ahmad, M., Smith, D.G., \& Mahboob, S. (2002). Effect on $\mathrm{NaCl}$ on heat tolerance of Enterococcus faecium and Enterococcus faecalis. Online Journal of Biological Sciences, 2(7), 483-484. doi: 10.3923/jbs.2002.483.484.

Allwood, M.M. \& Russell, A.D. (1970). Mechanisms of thermal injury in nonsporulating bacteria. Advances in Applied Microbiology, 12, 89-119. doi: 10.1016/S0065-2164 (08)70583-5
Andrews, L. S., Park, D. L., \& Chen, Y.P. (2000). Low temperature pasteurization to reduce the risk of vibrio infections from raw shell-stock oysters. Food Additives and Contaminant, 17(9), 787-91. doi: 10.1080/02652030041 5336787-791.

Badan Standardisasi Nasional. (1992). Standar Nasional Indonesia (SNI) 01-2891-1992: Cara uji makanan dan minuman. Jakarta: Badan Standardisasi Nasional.

Badan Standardisasi Nasional. (2008). Standar Nasional Indonesia (SNI 2897:2008): Metode pengujian cemaran mikroba dalam daging, telur dan susu, serta hasil olahannya, Jakarta: Badan Standardisasi Nasional.

Bayles, D.O. (2004). Changes in heat resistance resulting from $\mathrm{pH}$ and nutritional shifts of acid-adapted and non-acidadapted Listeria monocytogenes Scott A. Journal of Food Protection, 67(2), 316-321, doi: 10.4315/0362-028X67.2.316.

Cebrián, G., Condón, S., \& Mañas, P. (2017). Physiology of the inactivation of vegetative bacteria by thermal treatments: mode of action, influence of environmental factors, and inactivation kinetics. Foods, 6, 107. doi: 10.3390/foods612 0107.

Chirife, J., \& Resnik, S. L. (1984). Unsaturated solutions of sodium chloride as reference sources of water activity at various temperatures. Journal of Food Science, 49(6), 14861488. doi:10.1111/j.1365-2621.1984.tb12827.x

Christiansen, P., Nielsen, E.W., Vogensen, F.K., Brogren, C.H., \& Ardo, Y. (2006). Heat resistance of Lactobacillus paracasei isolated from semi-hard cheese made of pasteurized milk. International Dairy Journal, 16, 1196-1204. doi: 10.1016/ j.idairyj.2005.10.009.

Corradini, M.G., Normand, M.D., \& Peleg, M. (2007). Modeling non-isothermal heat inactivation of microorganisms having bi-phasic isothermal survival curves. International Journal of Food Microbiology, 116, 391-399. doi: 10.1016/j.ijfood micro.2007.02.004.

De Angelis, M., \& Gobbetti, M. (2004). Environmental stress responses in Lactobacillus: a review. Proteomics, 4(1), 106122. doi: 10.1002/pmic.200300497.

de Jonge, R. (2019). Predictable and unpredictable survival of foodborne pathogens during non-isothermal heating. International Journal of Food Microbiology, 291(16), 151160. doi: 10.1016/j.ijfoodmicro.2018.11.018

den Besten, H.M.W., Wells-Bennik, M.H.J., \& Zwietering, M.H. (2018). Natural diversity in heat resistance of bacteria and bacterial spores: impact on food safety and quality. Annual Review of Food Science and Technology, 9(1), 383410. doi: 10.1146/annurev-food-030117-012808.

Desniar, Rusmana, I., Suwanto, A., \& Mubarik, N.R. (2013). Characterization of lactic acid bacteria isolated from an Indonesian fermented fish (bekasam) and their antimicrobial activity against pathogenic bacteria. Emirates Journal of Food and Agriculture, 25(6), 489-494. doi: 10.9755/ ejfa.v25i6.12478.

Donnet-Hughes, A., Rochat, F., Serrant, P., Aeschlimann, J.M., \& Schiffrin, E.J. (1999). Modulation of nonspecific mechanisms of defense by lactic acid bacteria: effective dose. Journal of Dairy Science, 82(5),863-869. doi: 10.3168/ jds.S0022-0302(99)75304-X.

Doyle, M.E., Mazzotta, A.S., Wang, T., Wiseman, D.W., \& Scott, V.N. (2001). Heat Resistance of Listeria 
monocytogenes. Journal of Food Protection, 64(3), 410429. doi: 10.4315/0362-028X-64.3.410.

Fabbri, A.D.T, \& Crosby, G.A. (2016). A review of the impact of preparation and cooking on the nutritional quality of vegetables and legumes. International Journal of Gastronomy and Food Science, 3, 2-11.

Ferrando, V., Quiberoni, A., Reinhemer, J., \& Suarez, V. (2015). Resistance of functional Lactobacillus plantarum strains against food stress conditions. Food Microbiology, 48, 6371. doi: 10.1016/j.fm.2014.12.005.

Flahaut, S., Frere, J., Boutibonnes, P., \& Auffray, Y. 1997. Relationship between the thermotolerance and the increase of DnaK and GroEL synthesis in Enterococcus faecalis ATCC 19433. Journal of Basic Microbiology, 37(4), 251258. doi: 10.1002/jobm.3620370404.

Guarner, F., \& Schaafsma, G.J. (1998). Probiotics. International Journal of Food Microbiology, 39, 237-238. doi: 10.1016/ s0168-1605(97)00136-0.

Hackney, C.R., Rippen, T.E. \& Ward, D.R. (1991). Principles of pasteurization and minimally processed seafoods in D.R. Ward et al. (eds) Microbiology of marine food products. Van Nostrand Reinhold, p. 355-371.

Haddaji, N., Krifi, B., Lagha, R., Khouadja, S., \& Bakhrouf, A. 2015. Effect of high temperature on viability of Lactobacillus casei and analysis of secreted and GroEL proteins profiles. African Journal of Bacteriology Research, 7(3), 29-34. doi: 10.5897/JBR2015.0155.

Horn, B., Olsen, L., Hasell, S., \& Cook, R. (2015) Standardization of parameters for pathogen control in food: $D$ and $z$ values for the heat inactivation of pathogens in raw meat. MPI Technical Paper No: 2016/05. Ministry for Primary Industries, New Zealand.

Huda, N. (2012). Indonesian fermented fish products. In Hui, Y.H., \& Evranuz, E.O. eds. Handbook of Animal-Based Fermented Food and Beverage Technology 2nd Edition. Boca Raton, FL: CRC Press.

Huertas, J.P., Aznar, A., Esnoz, A., Fernandez, P.S., Iguaz, A., Periago, P.M., \& Palop, A. (2016). High heating rates affect greatly the inactivation rate of Escherichia coli. Frontiers in Microbiology, 7, 1256. doi: 10.3389/fmicb.2016.01256.

Jordan, K.N., \& Cogan, T.M. (1999). Heat resistance of Lactobacillus spp. isolated from cheddar cheese. Letters in Applied Microbiology, 29,136-140. doi: 10.1046/j.13652672.1999.00607.x.

Kang, I.B., Kim, D.H., Jeong, D., Park, J.H., Lim, H.W., \& Seo, K.H. (2018). Heat resistance of Salmonella Enteritidis in four different liquid egg products and the performance and equivalent conditions of Ministry of Food and Drug Safety of South Korea and US Department of Agriculture protocols. Food Control, 94, 1-6. doi: 10.1016/j.foodcont.2018.06.024

Kim, C., Bushlaibi, M., Alrefaei, R., Ndegwa, E., Kaseloo, P, \& Wynn, C. (2019). Influence of prior $\mathrm{pH}$ and thermal stresses on thermal tolerance of foodborne pathogens. Food Science and Nutrition, 7(6), 2033-2042. doi:10.1002/fsn3.1034

Lestari, S.D., Ridhowati, S., \& Nopianti, R. (2017). Screening of lactic acid bacteria with probiotic potential from some fermented fish products (Rasbora argyrotaenia). Final Report on Science Technology and Arts Research. Sriwijaya University, Indonesia.
Lombard, K., Peffley, E.B., Geoffriau, E., Thompson, L., \& Herring, A. (2005). Quercetin in onion (Allium cepa L.) after heat-treatment simulating home preparation. Journal of Food Composition and Analysis, 18(6), 571-581. doi: 10.1016/ j.jfca.2004.03.027.

Lozano-Castellón, J., Vallverdú-Queralt, A., de Alvarenga, J.F.R., Illán M., Torrado-Prat, X., \& Lamuela-Raventós, R.M. (2020). Domestic sautéing with EVOO: change in the phenolic profile. Antioxidants, 9(77). doi:10.3390/ antiox9010077.

Martýnez, S., Lopez, M., \& Bernardo, A. (2003). Thermal inactivation of Enterococcus faecium: effect of growth temperature and physiological state of microbial cells. Letters in Applied Microbiology, 37, 475-481. doi: 10.1046/ j.1472-765X.2003.01431.x.

McAuley, C. M., Gobius, K. S., Britz, M. L., \& Craven, H. M. (2012). Heat resistance of thermoduric enterococci isolated from milk. International Journal of Food Microbiology, 154(3), 162-168. doi:10.1016/j.ijfoodmicro.2011.12.033.

McCormick, K., Han, I.Y., Acton, J.C., Sheldon, B.W., \& Dawson P.L. (2003). D and z-values for Listeria monocytogenes and Salmonella Typhimurium in packaged low-fat ready-to-eat turkey bologna subjected to a surface pasteurization treatment. Poultry Science, 82(8), 1337-1342. doi: 10.1093/ $\mathrm{ps} / 82.8 .1337$

Nuraini, A., Ibrahim, R., \& Rianingsih, L. (2014). The effect of different concentrations addition of cooked rice as carbohydrates sources and brown sugars to the quality "bekasam" made of red tilapia (Oreochromis niloticus). Jurnal Saintek Perikanan, 10(1), 19-25.

Nurnaafi, A., Setyaningsih, I., \& Desniar. (2015). Probiotic potential of bekasam lactic acid bacteria of tilapia fish. Jurnal Teknologi dan Industri Pangan, 26(1), 109-114.

Palop, A., \& Martínez, A. (2012). pH-assisted thermal processing in D-W. Sun (Ed) Thermal food processing: new technologies and quality issues. Boca Raton, FL: CRC Press Taylor and Francis Group.

Pérez-Chabela, M.d.L., Totosaus, A., \& Guerrero, I. (2008). Evaluation of thermotolerant capacity of lactic acid bacteria isolated from commercial sausages and the effects of their addition on the quality of cooked sausages. Ciência $e$ Tecnologia de Alimentos, 28(1), 132-138. doi: 10.1590/ S0101-20612008000100019.

Putri, D.M., Budiharjo, A., \& Kusdiyantini, E. (2014). Isolasi, karakterisasi bakteri asam laktat, dan analisis proksimat dari pangan fermentasi rusip ikan teri (Stolephorus sp.). Jurnal Biologi, 3(2), 11-19.

Rimadhini, F.N., Sumardianto \& Romadhon. (2020). Antibacterial activity of lactic acid bacteria isolated from rusip ikan teri (Stolephorus sp.) with difference liquid palm sugar concentration. Jurnal Ilmu dan Teknologi Perikanan, $2(1), 54-63$.

Rinto, R., Lestari, S. D., \& Putri, N. A. (2019). Aktivitas antioksidan dan antikolesterol ekstrak rusip. Jurnal Pascapanen dan Bioteknologi Kelautan dan Perikanan, 14(1), 1-8. doi: 10.15578/jpbkp.v14i1.568.

Savedboworn, W., Riansa-ngawong, W., Sinlapacharoen, W., Pajakang, S., Patcharajarukit, B., \& Tipkanon, S. (2014). Assessment of probiotic properties in lactic acid bacteria 
isolated from fermented vegetables. KMUTNB International Journal of Applied Science and Technology, 7(4), 53-65. doi: 10.14416/j.ijast.2014.10.001.

Schumann, W. (2017). Regulation of the heat shock response in bacteria in C. M. Santosh Kumar \& SC Mande (eds.) Heat shock proteins. Singapore: Springer Nature Singapore Pte Ltd. doi: 10.1007/978-981-10-4651-3_2.

Shah N.P., Ali, J.F., \& Ravula, R.K. (2000). Populations of $L$. acidophilus, Bifidobacterium spp., and Lactobacillus casei in commercial fermented milk products. Bioscience and Microflora, 19, 35-39. doi: 10.12938/bifidus1996.19.35.

Shin, Y., Kang, C.-H., Kim, W., \& So, J.-S. (2018). Heat adaptation improved cell viability of probiotic Enterococcus faecium HL7 upon various environmental stresses. Probiotics and Antimicrobial Proteins. 11(2), 618-626. doi:10.1007/s 12602-018-9400-4.

Sornplang, P. \& Piyadeatsoontorn, S. (2016). Probiotic isolates from unconventional sources: a review. Journal of Animal Science and Technology, 58:26. doi: 10.1186/s40781-0160108-2.

Sorqvist, S. 2003. Heat resistance in liquids of Enterococcus spp., Listeria spp., Escherichia coli, Yersinia enterocolitica, Salmonella spp. and Campylobacter spp. Acta Veterinaria Scandinavica, 44(1-2),1-19. doi: 10.1186/1751-0147-44-1.
Tadapaneni, R. K., Syamaladevi, R. M., Villa-Rojas, R., \& Tang, J. (2017). Design of a novel test cell to study the influence of water activity on the thermal resistance of Salmonella in low-moisture foods. Journal of Food Engineering, 208, 4856. doi: 10.1016/j.jfoodeng.2017.03.025.

US Food \& Drug Administration. (2001). Bacteriological Analytical Manual (BAM). https://www.fda.gov/food/ laboratory-methods-food/bam-r63-physiological-salinesolution-085-sterile

US Food and Drug Administration. (2018). Guidance for Industry: Hazard Analysis and Risk-Based Preventive Controls for Human Food, Chapter 4.

US Food and Drug Administration. (2020). Fish and Fishery Products Hazards and Controls Guidance Fourth Edition, Chapter 16.

Wikandari, P.R., Suparmo, Marsono, Y., Rahayu, E.S. (2012). Karakterisasi bakteri asam laktat proteolitik pada bekasam. Jurnal Natur Indonesia, 14(2), 120-125

Wu, V.C. (2008). A review of microbial injury and recovery methods in food. Food Microbiology, 25, 735-744. doi: 10.1016/j.fm.2008.04.011.

Yuliana, N., Koesoemawardani, D., Susilawaty, \& Kurniati, Y. (2018). Lactic acid bacteria during fish fermentation (rusip). MOJ Food Processing \& Technology, 6(2), 211-216. doi: 10.15406/mojfpt.2018.06.00167. 